\title{
Perbandingan Pengaturan Perlindungan Saksi Tindak Pidana Pencucian Uang
}

\author{
Ahmad Dahlan, Usman, Herry Liyus \\ Fakultas Hukum, Universitas Jambi \\ Author's Email Correspondence: ahmddahlann12@gmail.com
}

\begin{abstract}
ABSTRAK
Artikel ini bertujuan untuk mengetahui dan menganalisis persamaan dan perbedaan perlindungan saksi tindak pidana pencucian uang di Indonesia dan Malaysia. Jenis penelitian yuridis normatif. Teknik pengumpulan data yang digunakan yaitu melalui pengumpulan data-data sekunder. Teknik pengumpulan data dilakukan dengan studi kepustakaan untuk mengumpulkan dan menyusun data yang berhubungan dengan masalah yang diteliti, dengan cara menginventarisasi dan mempelajari peraturan perundang- undangan, buku-buku, tulisan-tulisan dan dokumen yang berhubungan dengan masalah yang penulis teliti. Teknik analisis data dengan analisis isi (content). Hasil yang diperoleh dari penelitian ini yaitu bahwa pengaturan perlindungan saksi di Indonesia dan Malaysia adalah berbeda. Dalam hal subjek yang dilindungi (yaitu: saksi, pelapor, keluarga saksi/pelapor). Perlindungan yang diberikan pada semua tahap pemeriksaan perkara, dalam bentuk perlindungan khusus dan hukum. Sedangkan di Malaysia, pelaksanaanya hanya merujuk pada ketentuan perlindungan saksi. Perlindungan hanya berupa perlindungan hukum yang diberikan kepada saksi pelapor saja, sehingga dalam selama proses persidangan, seorang saksi tidak mendapat perlindungan.
\end{abstract}

Kata Kunci: Pencucian uang; perlindungan; saksi.

\section{ARTICLE HISTORY}

Submission: 2021-02-24

Accepted: 2021-04-22

Publish: 2021-04-26

\section{KEYWORDS:}

Money laundering; protection; witness

\begin{abstract}
This article aims to find out and analyze the similarities and differences in the protection of witnesses to the crime of money laundering in law of Indonesia and Malaysia. The research method used is normative juridicial. The data collection techniques used are secondary data collection that carried out by library research to collect and compile data related to the problem under study, by taking an inventory and studying laws and regulations, books, writings and documents related to the issues that the author examined. The data analysis techniques with content analysis. The results obtained from this study are that the arrangements for witness protection in the Money Laundering Law in Indonesia and Malaysia are different. protected subjects (namely: witness, the reporter, the family of the witness/reporter) as well as the broader arrangements in Indonesia as well as in its implementation special protection arrangements have been made in the PP and Decree of the Chief of the Indonesian National Police. Protection provided at all stages of case examination, in the form of special and legal protections. Whereas in Malaysia, the implementation only refers to the provisions of witness protection. Protection only takes the form of legal protection provided to reporting witnesses only, so that during the trial process, a witness has no protection.
\end{abstract}




\section{A. PENDAHULUAN}

Pencucian uang (money laundering) merupakan suatu kejahatan yang sering terjadi, karena terjadi secara internasional, dan terjadi pula di Indonesia. Bahkan pencucian uang (money laundering) dapat menimbulkan dampak negatif yang sangat besar terhadap perekonomian dari suatu negara, baik langsung maupun tidak langsung pencucian uang dapat mempengaruhi sistem perekonomian itu sendiri. Di dalam praktek money laundering telah diketahui banyak sekali dana yang potensial tidak dimanfaatkan secara optimal, karena pelaku money laundering sering sekali melakukan "steril investment" misalnya saja investasi dibidang properti pada negara negara yang mereka anggap aman, walaupun dengan melakukan hal itu hasil yang diperoleh jauh lebih rendah. ${ }^{1}$

Pencucian uang atau money laundering secara sederhana diartikan sebagai suatu proses menjadikan hasil kejahatan (procced of crime) atau disebut sebagai uang kotor (dirty money) misalnya hasil dari obat bius, korupsi, penggelapan pajak, judi, penyelundupan dan lain-lain yang di konversi atau diubah kedalam bentuk yang tampak sah agar dapat digunakan dengan aman.terdapat berbagai rumusan tindak pidana pencucian uang, selain itu dinyatakan bahwa tidak ada definisi pencucian uang yang bersifat universal, artinya setiap negara boleh merumuskan sesuai definisi negaranya, terutama dalam menentukan jenis kejahatan asalnya. ${ }^{2}$

Sebagai kejahatan yang bersifat lintas negara (transnational crime), tindak pidana pencucian uang (money laundering) modusnya banyak dilakukan melintasi batas batas negara, dan berdampak negatif pada sistem keuangan dan perekonomian dunia secara keseluruhan.di sisi lain oleh karena tindak pidana pencucian uang (money laundering) berkaitan dengan kejahatan asal yang dilakukan oleh organized crime, maka berkembangnya tindak pidana pencucian uang (money laundering) akan sangat mempengaruhi tumbuh dan berkembangnya berbagai tindak pidana pemicu pencucian uang, seperti korupsi, perdagangan gelap narkotika dan illegal loging serta upaya untuk memeranginya. ${ }^{3}$

Sepintas, tampaknya pencucian uang tidak merugikan orang atau negara, namun sebenarnya pencucian uang telah menimbulkan kerugian yang meluas, tidak hanya disektor ekonomi, tetapi juga diseluruh sektor kehidupan, mulai dari rusaknya reputasi negara sampai meningkatnya jumlah kejahatan awal (prediate crimes) dari tindak pidana pencucian uang. Selain itu tindak pidana pencucian uang juga berpotensi untuk merongrong sektor keuangan sebagai akibat demikian besarnya jumlah uang yang terlibat dalam kegiatan tersebut. ${ }^{4}$

Dalam proses pemeriksaan perkara pidana meneganai kasus pencucian uang, saksi adalah salah satu kunci untuk memperleh kebenaran materiil, yang merupakan kebenaran yang benar benar terjadi. Salah satu alat bukti yang sah dalam proses peradilan pidana adalah keterangan saksi yang mendengar, melihat atau mengalami

1 Bismar Nasution, Resim Anti Money Laundering di Indonesia, Books Terrace, Bandung, 2008, hlm. 1.

2 Yenti Garnasih, Penegakan Hukum Anti Pencucian Uang dan Permasalahnnya di Indonesia, Rajawali Pers, Depok, 2017, hlm. 1.

3 Sutan Remy Sjahdeini, Seluk Beluk Tindak Pidana Pencucian Uang dn Pembiayaan Terorisme, Pusat Utama Grafiti, Jakarta, 2004, hlm. 5.

4 Ibid. hlm. 19 
sendiri terjadinya suatu tindak pidana dalam upaya mencari dan menemukan kejelasan tentang tindak pidana yang dilakukan oleh pelaku tindak pidana.

Adapun pentingnya saksi dalam tahap penyelidikan dikemukakan oleh Kabib Nawawi dan Aprillani Arsyad :

"Dalam tahap penyelidikan sampai pembuktian dimuka sidang pengadilan, kedudukan saksi sangatlah penting, bahkan dalam praktek sering menjadi penentu dan keberhasilan dalam mengungkapkan suatu kasus, karena bias memberikan "keterangan saksi" yang menjadi alat bukti pertama dari alat bukti yang sah sebagaimana diatur dalam pasal $184 \mathrm{KUHAP}^{\text {" }}{ }^{5}$

Di dalam pembuktian tindak pidana terdapat alat alat bukti yang sah yang dijelaskan pasal 184 ayat 1 kuhap yang berbunyi :

(1). Alat bukti yang sah :

a. Keterangan Saksi

b. Keterangan Ahli

c. Surat

d. Petunjuk

e. Keterangan terdakwa

(2). Hal yang secara umum sudah diketahui tidak perlu dibuktikan.

Adapun pentingnya alat bukti di dalam suatu tindak pidana yang dikemukakan oleh Hafrida :

"Alat bukti sangatlah penting, karena dengan adaya alat bukti akan terungkap jelas dan terang benderang dari suatu pristiwa. Alat bukti adalah alat alat yang ada hubungan nya dengan suatu tindak pidana, dimana alat alat tersebut dapat digunakan sebagai bahan pembuktian guna menimbulkan keyakinan bagi hakim atas kebenaran adanya suatu tindak pidana yang telah dilakukan oleh terdakwa". ${ }^{6}$

Dengan demikian keberadaan saksi merupakan suatu elemen yang sangat menentukan dalam suatu proses peradilan pidana. Namun demikian ternyata peran saksi dalam proses peradilan masih jauh dari perhatian masyarakat dan penegak hukum.telah banyak sekali kasus-kasus yang tidak terungkap dan juga tidak terselaikan, oleh Karena keenggana saksi untuk memberikan informasi kepada pihak yang berwenang. Bahkan pada saat ini posisi saksi (termasuk saksi korban) dalam proses peradilan pidana di Indonesia hanyalah dipandang sebagai alat yang dapat memperkuat posisi jaksa dipersidangan.

Mencermati kondisi yang tampak belum bekesesuaian diatas, kita sebenarnya sudah dapat mengkap suatu alur pikir bahwa untuk menciptakan suatu kesesuaian yang berkualitas hanya dapat diperoleh jika ancaman-ancaman baik yang bersifat fisik maupun psikis terhadap saksi (saksi pelapor, saksi biasa, saksi ahli), kerugian-kerugian materiil dan berbagai masalah lain yang menjadi kendala dapat dihilangkan, salah satu cara yang dapat diberlakukan adalah dengan memberikan perlindungan kepada saksi,

5 Kabib Nawawi Dan Aprillani Arsyad, "Meningkatkan Pemahaman Masyaraka Terhadap Undang-Undang No.31 Tahun 2014 Tentang Perlindungan Saksi Dan Korban Di Desa Kayu Aro Kecamatan Muara Bulian Kabupaten Batanghari". Jurnal Pengabdian Pada Masyarakat, Vol. 31, No. 2, 2016, hlm. 7. https://scholar.google.co.id/citations?user=8InHKN8AAAAJ\&hl=id.

6 Hafrida, "Perekaman Proses Persidangan Pada Pengadilan Negeri Di Tinjau Dari Aspek Hukum Acara Pidana”, Jurnal Ilmu Hukum, Vol. 5, No. 1, 2014, hlm. 16. https://scholar.google. com/citations?user=xT8MpbIAAAAJ\&hl=en 
khususnya dalam hal ini adalah saksi yang berkaitan dengan tindak pidana pencucian uang.

Berkenaan dengan adanya ketidakpercayaan Saksi dan Korban, maka adanya satu instrumen yuridis yang mengatur tentang perlindungan Saksi dan Korban dalam bentuk undang-undang sangat penting adanya. Tujuannya bukan hanya semata-mata untuk mendukung proses peradilan dan penyelesaian perkara secara lebih adil dan kompeten, tetapi juga untuk menunjukkan adanya tanggung jawab negara terhadap warga negaranya yang telah mengalami berbagai tindak pelanggaran hukum.

Pelaksanaan perlindungan saksi tindak pidana pencucian uang ini tidak hanya di atur di negara Indonesia saja, tetapi juga terdapat di negara-negara yang menganut sistem common law, salah satunya yaitu di negara Malaysia. Di negara Malaysia pengaturan tentang perlindungan saksi tindak pidana pencucian uang di kenal dengan NamaAkta Pencegahan Pengubahan Wang Haram, Pencegahan Pembiayaan Keganasan dan Hasil daripada Aktiviti Haram 2001 (AKTA 613) . Dalam peraturan ini perlindungan saksi tindak pidana pencucian uang hanya sebatas perlindungan bagi saksi dan pelapor saja, tidak seperti di Indonesia perlindungan saksi tindak pidana pencucian uang lebih terperinci dibahas di undang undang No. 8 Tahun 2010 tentang Pencegahan dan Pemberantasan Tindak Pidana Pencucian Uang.

Perbedaan mendasar dari kedua peraturan ini adalah pada Indonesia pengaturan perlindungan saksi tindak pidana pencucian uang diatur lebih terperinci dalam UU No. 8 Tahun 2010 tentang Pencegahan dan Pemberantasan Tindak Pidana Pencucian Uang diatur dalam BAB tersendiri yaitu BAB IX pasal 83 s.d pasal 87 yaitu kewajiban untuk merahasiakan identitas palapor, Kewajiban untuk memberikan perlindungan khusus oleh negara terhadap setiap orang yang melaporkan terjadinya dugaan TPPU, baik dari kemungkinan ancaman yang membahayakan diri, jiwa, dan/atau hartanya, termasuk keluarganya. Pelarangan untuk menyebut nama atau alamat pelapor, atau hal-hal lain yang memungkinkan dapat terungkapnya identitas pelapor di sidang pengadilan. Kewajiban untuk memberikan perlindungan khusus oleh negara terhadap setiap orang yang memberikan kesaksian dalam pemeriksaan TPPU, baik dari kemungkinan ancaman yang membahayakan diri, jiwa, dan/atau hartanya, termasuk keluarganya.serta Pemberian jaminan kepada pelapor dan/atau saksi sehingga tidak dapat dituntut baik secara perdata atau pidana atas pelaporan dan/atau kesaksian yang diberikan oleh yang bersangkutan.

Di dalam melaksanakan Perlindungan Saksi Tindak Pidana Pencucian Uang, setiap negara harus memiliki Pedoman tertentu dalam melakukan Perlindungan Saksi Tindak Pidana Pencucain Uang, Agar memberikan rasa aman terhadap Saksi/Pelapor, dengan demikian Perlindungan yang di berikan lebih efektif dan berjalan dengan baik, Pedoman yang di maksud adalah harus berdasarkan UNITED NATIONS CONVENTION AGAINST CORRUPTION (UNCAC), 2003. Yaitu terdapat di dalam Pasal 32 a dan b yang berbunyi :

Pasal 32:

Perlindungan Saksi-Saksi, Para Saksi Ahli dan Para (Saksi) Korban

a) Setiap warga peserta wajib mengambil tindakan-tindakan yang tepat sesuai dengan sistem hukum yang berlaku dinegaranya, dan dengan cara menyediakan perlindungan yang efektif dari perlindungan yang efektif dari kemungkinan balasan atau ancaman/intimidasi terhadap para saksi dan para saksi ahli yang memberikan kesaksian mengenai tindak pidana yang ditetapkan sesuai dengan konvensi ini, 
serta sejauh diperlukan bagi keluarga mereka dan orang orang lain yang dekat dengan mereka.

b) Tindakan-tindakan yang digambarkan dalam ayat 1 pasal ini dapat meliputi, antara lain, tanpa [mengurangi][menghilamgkan] hak-hak terdakwa, termasuk untuk mendapat peradilan yang wajar :

(i) Menentukan [Prosedur] perlindungan fisik orang-orang tersebut seperti, sejauh diperlukan dan dimungkinkan merelokasi mereka dan mengizinkan, dimana wajar, [ketidakterbukaan] atau pembatasan-pembatasan penyingkapan informasi tentang identitas dan keberadaan dari orang-orang tersebut;

(ii) Menyediakan hukum pembuktian yang membolehkan saksi-saksi dan ahli-ahli memberikan kesaksian dengan cara yang menjamin keselamatan orang-orang tersebut, seperti memberikan kesaksian diberikan dengan menggunakan teknologi komunikasi seperti video atau sarana sarana yang memadai.

Dari penjelasan pasal diatas,menyebutkan bahwa perlindungan saksi tindak pidana pencucian uang harus mengikut sertakan saksi, pelapor, dan keluarga saksi pelapor, hal ini telah dilakukan di Indonesia yang terdapat didalam Undang-Undang No. 8 Tahun 2010. Namun, di dalam UU Malaysia (Akta Pencegahan Pengubahan Wang Haram, Pencegahan Pembiayaan Keganasan dan Hasil daripada Aktiviti Haram 2001 (AKTA 613), Malaysia tidak mengikut sertakan keluarga dan saksi dalam melakukan Perlindungan Saksi Tindak Pidana pencucian Uang di negaranya, Hal ini tentu tidak sesuai dengan UNITED NATIONS CONVENTION AGAINST CORRUPTION (UNCAC), 2003.

Dari penjelasan diatas, penulis merasa tertarik dengan kedua hukum di dua negara ini penulis ingin melihat perbedaan dan persamaan serta keunggulan dan kelemahan dari masing masing pengaturan di kedua negara tersebut.

\section{B. METODE PENELITIAN}

Penelitian ini bersifat yuridis normatif. Tehnik pengumpulan data yang digunakan yaitu melalui pengumpulan data-data sekunder. Teknik pengumpulan data dilakukan dengan studi kepustakaan untuk mengumpulkan dan menyusun data yang berhubungan dengan masalah yang diteliti, dengan cara menginventarisasi dan mempelajari peraturan perundang- undangan, buku-buku, tulisan-tulisan dan dokumen yang berhubungan dengan masalah yang penulis teliti.

\section{PEMBAHASAN}

1. Persamaan dan Perbedaan Perlindungan Saksi Tindak Pidana Pencucian Uang di Negara Indonesia dan Malaysia

Di Indonesia Undang-Undang yang mengatur Perlindungan Saksi Tindak Pidana Pencucian Uang yaitu Undang-Undang Nomor 8 Tahun 2010. Dalam Undang-Undang tersebut terdapat 5 (lima) pasal yang mengatur tentang Perlindungan Saksi tindak pidana Pencucian Uang antara lain :

1. Pasal 83 Ayat (1) dan (2).

(1) Pejabat dan pegawai PPATK, penyidik, penuntut umum, atau hakim wajib merahasiakan Pihak Pelapor dan pelapor.

(2) Pelanggaran terhadap ketentuan sebagaimana dimaksud pada ayat (1) memberikan hak kepada pelapor atau ahli warisnya untuk menuntut ganti kerugian melalui pengadilan. 
2. Pasal 84 Ayat (1) dan (2).

(1) Setiap Orang yang melaporkan terjadinya dugaan tindak pidana Pencucian Uang wajib diberi pelindungan khusus oleh negara dari kemungkinan ancaman yang membahayakan diri, jiwa, dan/atau hartanya, termasuk keluarganya.

(2) Ketentuan mengenai tata cara pemberian perlindungan khusus sebagaimana dimaksud pada ayat (1) diatur dalam peraturan perundang-undangan.

3. Pasal 85 Ayat (1) dan (2).

(1) Di sidang pengadilan, saksi, penuntut umum, hakim, dan orang lain yang terkait dengan tindak pidana Pencucian Uang yang sedang dalam pemeriksaan dilarang menyebutkan nama atau alamat pelapor atau hal lain yang memungkinkan dapat terungkapnya identitas pelapor.

(2) Dalam setiap persidangan sebelum sidang pemeriksaan dimulai, hakim wajib mengingatkan saksi, penuntut umum, dan orang lain yang terkait dengan pemeriksaan perkara tersebut mengenai larangan sebagaimana dimaksud pada ayat (1).

4. Pasal 86 Ayat (1) dan (2).

(1) Setiap orang yang memberikan kesaksian dalam pemeriksaan tindak pidana Pencucian Uang wajib diberi perlindungan khusus oleh negara dari kemungkinan ancaman yang membahayakan diri, jiwa, dan/atau hartanya, termasuk keluarganya.

(2) Ketentuan mengenai tata cara pemberian perlindungan khusus sebagaimana dimaksud pada ayat (1) diatur dalam peraturan perundang-undangan.

5. Pasal 87 Ayat (1) dan (2).

(1) Pelapor dan/atau saksi tidak dapat dituntut, baik secara perdata maupun pidana atas laporan dan/atau kesaksian yang diberikan oleh yang bersangkutan.

(2) Saksi yang memberikan keterangan palsu di atas sumpah dipidana sesuai dengan ketentuan dalam Kitab Undang-Undang Hukum Pidana.

Perlindungan terhadap seseorang yang menjadi pelapor dan/atau saksi ini begitu ketat sekali ditekankan di dalam undang-undang pencucian uang. Bahkan kepada semua pihak yang terkait dengan pemeriksaan perkara tindak pidana pencucian uang, seperti PPATK, penyidik, saksi, penuntut umum, hakim atau orang lainnya akan diberikan ancaman sanksi keras jika melakukan pelanggaran ketentuan tersebut di atas.Bahwa untuk melaksanakan ketentuan Pasal 84 ayat (2) dan Pasal 86 ayat (2) UU Tindak Pidana Pencucian Uang, perlu menetapkan Peraturan Pemerintah tentang Tata Cara Perlindungan Khusus bagi Pelapor dan Saksi Tindak Pidana Pencucian Uang, yang kemudian pada 11 November 2003, Presiden menetapkan Peraturan Pemerintah No. 57 Tahun 2003 tentang Tata Cara Perlindungan Khusus bagi Pelapor dan Saksi Tindak Pidana Pencucian Uang. PP No. 57 Tahun 2003 mengatur mengenai bentuk dan tata cara perlindungan khusus bagi pelapor dan saksi sebagai pengaturan teknis pelaksanaan perlindungan saksi money laundering.

Saksi tindak pidana Pencucian Uang berhak mendapatkan perlindungan atas dirinya. Perlindungan yang diberikan diharapkan memberikan jaminan atas rasa aman dan dapat memberikan keterangan yang benar, sehingga proses peradilan terhadap tindak pidana pencucian uang dapat dilaksanakan dengan baik. Dengan demikian pelapor dan saksi dapat berpartisipsi aktif dalam upaya pencegahan dan pemberantasan Tindak Pidana Pencucian Uang. Perlindungan yang diberikan adalah 
perlindungan khusus yang meliputi perlindungan atas keamanan pribadi dan/atau keluarga pelapor dan saksi dari ancaman fisik atau mental, perlindungan terhadap harta pelapor dan saksi, perahasiaan dan penyamaran identitas pelapor dan saksi, dan/atau pemberian keterangan tanpa bertatap muka dengan tersangka/terdakwa dalam setiap tingkat pemeriksaan.

Bentuk perlindungan khusus oleh Kepolisian Negara Republik Indonesia sebagaimana dimaksud dalam Pasal 2 ayat (2) PP No. 57 Th. 2003 dilaksanakan berdasarkan adanya kemungkinan ancaman yang membahayakan diri, jiwa, dan/atau harta, termasuk keluarga pelapor dan saksi sebagai akibat (Pasal 6 ayat (1) PP No. 57 Tahun 2003):

a) Disampaikannya laporan tentang adanya Transaksi Keuangan Mencurigakan atau Transaksi Keuangan yang Dilakukan Secara Tunai oleh pelapor sebagaimana dimaksud dalam Pasal 1 angka 2 huruf a atau PPATK kepada Kepolisian Negara Republik Indonesia;

b) Disampaikannya laporan tentang adanya dugaan terjadinya tindak pidana pencucian uang oleh pelapor sebagaimana dimaksud dalam Pasal 1 angka 2 huruf b atau PPATK kepada Kepolisian Negara Republik Indonesia; atau

c) Ditetapkannya seseorang sebagai saksi dalam perkara tindak pidana pencucian uang.

Perlindungan tersebut dilakukan dalam jangka waktu paling lambat 1 X 24 (satu kali dua puluh empat) jam sejak laporan diterima atau seseorang ditetapkan sebagai saksi yang ditindaklanjuti Kepolisian NRI dengan melakukan klarifikasi atas kebenaran laporan dan identifikasi bentuk perlindungan yang diperlukan serta melakukan pemberitahuan tertulis kepada pelapor dan/atau saksi paling lambat dalam jangka waktu 1 X 24 (satu kali dua puluh empat) jam sebelum pelaksanaan perlindungan (Pasal 6 ayat (2 dan 3) PP No. 57 Tahun 2003).

Pengajuan permohonan perlindungan khusus sebagaimana diatur dalam Pasal 7 dapat dilakukan oleh Pelapor, Saksi, PPATK, Penyidik, Penuntut Umum, atau Hakim. Dalam melaksanakan ketentuan perlindungan, Kepolisian NRI berkoordinasi dengan PPATK, Penyidik, Penuntut Umum, dan Hakim yang menangani perkara tindak pidana pencucian uang (Pasal 8 PP No. 57 Th. 2003). Teknis pelaksanaan perlindungan khusus sebagaimana dimaksud diatur dengan Keputusan Kepala Kepolisian Negara Republik Indonesia dengan memperhatikan masukan dari instansi terkait (Pasal 9 PP No. 57 Th. 2003).

Telah disebutkan di atas bahwa teknis pelaksanaan perlindungan khusus sebagaimana dimaksud dalam PP No. 57 Th. 2003, diatur dengan Keputusan Kepala Kepolisian Negara Republik Indonesia yang kemudian ditetapkan dengan Peraturan Kepala Kepolisian Negara Republik Indonesia Nomor Pol. 17 Tahun 2005 tentang Tata Cara Pemberian Perlindungan Khusus terhadap Pelapor dan Saksi dalam Tindak Pidana Pencucian Uang. Dalam Peraturan Kepala Kepolisian tersebut juga telah dilengkapi dengan pengaturan mengenai cara bertindak yang dilakukan bagi setiap anggota kepolisian dalam memberikan perlindungan baik kepada pelapor/ saksi. Perlindungan khusus adalah suatu bentuk perlindungan yang diberikan oleh aparat Kepolisian NRI untuk memberikan rasa aman terhadap pelapor atau saksi dari kemungkinan ancaman yang membahayahan diri, jiwa dan/atau hartanya termasuk keluarganya. 
Perlindungan diberikan terhadap segala ancaman, gangguan, teror, dan kekerasan adalah segala bentuk perbuatan memaksa yangbertujuan menghalanghalangi atau mencegah pelapor atau saksi, baik langsung atau tidak langsung mengakibatkan tidak dapat memberikan keterangan untuk kepentingan penyidikan, penuntutan, dan/atau pemeriksaan di sidang pengadilan. Pengelompokan bentuk perlindungan khusus tersebut meliputi 4 (empat) bentuk perlindungan. Yaitu :

1. Perlindungan atas keamanan pribadi dari ancaman fisik atau mental. Perlindungan ini meliputi orang, tempat/lokasi (baik pada rumah/penginapan/tempat tinggal; tempat kerja/kantor/tempat persidangan; rute dan sarana transportasi; dan tempat-tempat kegiatan lainnya) dan/atau kegiatan (pada tahap sebelum, saat dan sesudah proses pemeriksaan) terhadap pribadi pelapor, saksi dan keluarganya. Perlindungan diberikan terhadap kegiatan yang mungkin akan mendapat ganguan atau ancaman baik fisik (unjuk rasa, demonstrasi dan kerusuhan masa; penghadangan, perampokan, penculikan, penganiayaan dan pembunuhan; gangguan kendaraan, tempat/rumah/kantor dan tempat kegiatan lainnya; dan/atau sabotase) maupun mental (teror dan intimidasi/ ancaman terhadap keselamatan jiwa dan harta benda).

2. Perlindungan terhadap harta. Meliputi harta bergerak dan tidak bergerak, terutama yang paling memungkinkan menjadi sasaran gangguan pihak pelaku. Sasaran perlindungan didasarkan atas permohonan pelapor/saksi serta penilaian dari pejabat Polri.

3. Perlindungan atas perahasiaan dan penyamaran identitas. Dilaksanakan dengan merahasiakan dan menyamarkan nama, tempat/tanggal lahir (usia), jenis kelamin, alamat, pekerjaan, agama, status, pendidikan/gelar, kewarganegaraan dan suku bangsa. Meliputi cara bertindak untuk membuat berita acara penyamaran identitas berdasarkan permohonan pelapor/saksi dan menyimpan berita acara penyamaran tersebut serta menyerahkan berita acara penyamran setelah perkara dinyatakan lengkap kepada Jaksa Penuntut Umum.

4. Perlindungan atas pemberian keterangan tanpa bertatap muka (konfrontasi) dengan tersangka atau terdakwa pada setiap tingkat pemeriksaan meliputi tahap penyidikan, penuntutan, dan pemeriksaan di pengadilan.

Sedangkan di Malaysia Perlindungan Saksi Tindak Pidana Pencucian Uang diatur dalam Akta Pencegahan Pengubahan Wang Haram, Pencegahan Pembiayaan Keganasan dan Hasil daripada Aktiviti Haram 2001 (AKTA 613) terdapat pada pasal 24 yang berbunyi :

Perlindungan bagi saksi pelapor

(1) Tidak ada proses secara perdata, pidana atau ketertiban lainnya dapat dikenakan terhadap seseorang yang :

(a) mengungkapkan atau menyediakan segala informasi dalam segala laporan yang dibuat menurut undang-undang ini; atau

(b) menyediakan segala informasi yang berhubungan dengan suatu laporan, apakah pada saat laporan itu dibuat atau sesudahnya; Dalam hal :

1. pengungkapan atau penyediaan, atau cara pengungkapan atau penyediaan, oleh orang tersebut, dari informasi sesuai dalam paragraf (a) atau (b); atau 
2. segala akibat/dampak yang ditimbulkan/mengikuti pengungkapan atau penyediaan informasi tersebut, kecuali informasi yang diungkapkan atau disediakan dengan itikad tidak baik.

(2) Dalam proses/ tindakan yang dikenakan terhadap orang untuk suatu kejahatan menurut undang-undang ini, hal itu dapat menjadi suatu pembelaan bagi orang tersebut untuk menunjukkan bahwa dia sudah mengambil langkah yang beralasan dan melaksanakan semua hak yang baik atau sesuai untuk mencegah terjadinya kejahatan.

Pelaksanaan pemberian perlindungan saksi (saksi pelapor) khususnya dalam tindak pidana money laundering hanya didasarkan pengaturannya dalam Pasal 24A kta Pencegahan Pengubahan Wang Haram, Pencegahan Pembiayaan Keganasan dan Hasil daripada Aktiviti Haram 2001 (AKTA 613). Pengaturannya dalam peraturan pelaksanaan juga belum dibuat, bahkan payung hukum perlindungan saksi juga masih dalam tahap Rang (Rancangan) Undang- Undang Perlindungan Saksi (Witness Protection Bill). Rang Undang- Undang Perlindungan Saksi yang sedang digarap Parlimen Dewan Rakyat Malaysia baru-baru ini diharapkan dapat memberikan jaminan bahwa saksi akan diberikan sepenuhnya perlindungan undang-undang, termasuk mengubah identitas saksi jika diperlukan. Rang Undang-Undang Perlindungan Saksi yang hampir sampai pada tingkat akhir pembentukannya ini, ditujukan untuk memberikan perlindungan kepada seorang saksi yang memberikan keterangan dalam keseluruhan proses penindakan kejahatan (kes jenayah) dan tidak lagi hanya diatur mengenai saksi pelapor saja. Oleh karena pemberi maklumat (saksi pelapor) lazimnya menjadi saksi maka mereka sudah tentulah akan dilindungi di bawah akta ini. Rang Undang-undang ini juga akan menubuhkan satu program bagi perlindungan saksi. Mengenai lembaga yang melaksanakan pemberian bantuan dan perlindungan saksi di Malaysia juga belum dibentuk.

Malaysia menganut sistem hukum common law. Dapat dilihat bahwa kekuasaan hakim di dalam sistem hukum common law sangat luas dalam memberikan penafsiran terhadap suatu ketentuan yang tercantum dalam undang-undang. Bahkan hakim diperbolehkan tidak sepenuhnya bertumpu pada ketentuan suatu undang-undang jika diyakini olehnya bahwa ketentuan tersebut tidak dapat diterapkan dalam kasus pidana yang sedang dihadapinya. Dalam hal demikian hakim dapat menjatuhkan putusannya sesuai dengan kebiasaan-kebiasaan. Dilihat dari segi kekuasaan hakim yang sangat luas dalam memberikan penafsiran tersebut, sehingga dapat membentuk hukum baru, maka nampaknya sistem hukum common law kurang memperhatikan kepastian hukum.

Dari uraian pengaturan pemberian perlindungan saksi dalam undang- undang pencucian uang antara Negara Indonesia dan Malaysia ada terdapat perbedaan dan persamaannya, dan terdapat kelebihan dan kekurangan masing- masing negara dalam melakukan perlindungan saksi tindak pidana pencucian uang diantaranya dapat kita lihat pada tabel berikut : 
Tabel

Perbandingan perlindungan saksi tindak pidana pencucian Uang di Indonesia dan Malaysia

$\begin{array}{lll}\text { Perbandingan } \quad \text { Indonesia } & \text { Malaysia }\end{array}$

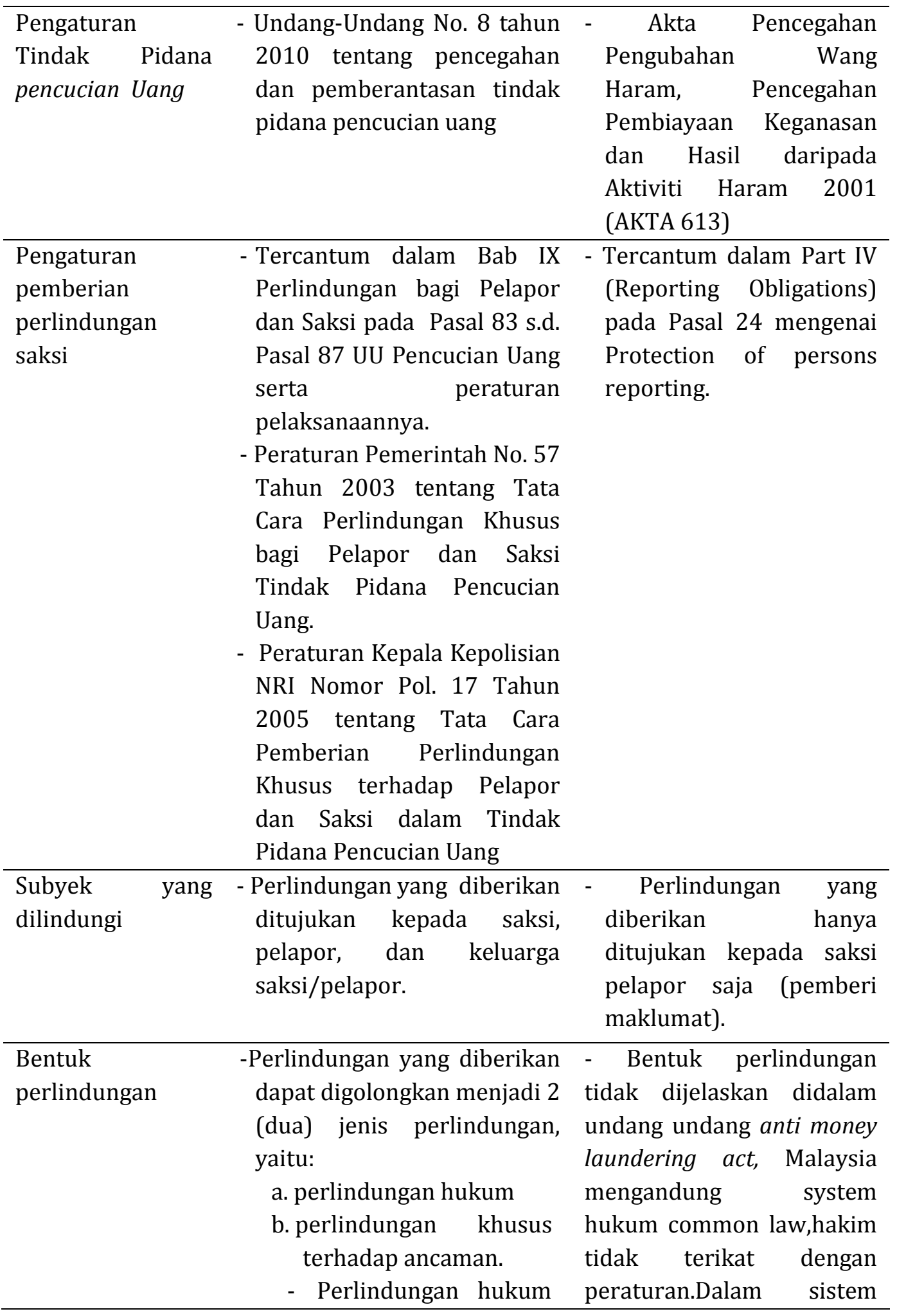


PAMPAS: Journal of Criminal Law Vol. 2, No. 1

\section{meliputi :}

a. Pelapor dan saksi untuk tidak dapat

dituntut baik secara perdata ataupun pidana sepanjang yang bersangkutan memberikan kesaksian atau laporan dengan itikad baik atau yang bersangkutan tidak pernah sebagai pelaku tindak pidana itu sendiri.

b. Larangan siapapun membocorkan pelapor dan kewajiban merahasiakan nama pelapor disertai dengan ancaman pidana terhadap pelanggarnya

Yang perlindungan khusus terhdap ancaman yang meliputi 4 (empat) bentuk perlindungan yaitu :

1. Perlindungan atas nama pribadi dari ancaman fisik atau mental

2. Perlindungan terhadap harta. Meliputi harta bergerak dan harta tidak bergerak, terutama yang paling memungkinkan

menjadi sasaran gangguan gangguan pihak pelaku

3. Perlindungan atas perahasiaan dan penyamaran identitas.

4. Perlindungan atas pemberian keterangan

\section{common law, hakim}

diperbolehkan tidak sepenuhnya bertumpu

pada ketentuan suatu Undang-Undang. Jika diyakini olehnya bahwa ketentuan yang dimaksud tidak dapat diterapkan dalam kasus yang sedang ditanganinya. Hakim cenderung bersifat judge made law, jadi dalam hal penerapan pengaturan perlindungan saksi dalam kasus-kasus yang ada, walaupun pengaturannya kurang dan sangat sempit karena hanya melindungi saksi pelapor, namun disini hakim dapat menentukan alternatif perlakuan bagi saksi yang bukan saksi pelapor 


\begin{tabular}{|c|c|c|c|}
\hline & & $\begin{array}{l}\text { tanpa bertatap muka } \\
\text { (konfrontasi) dengan } \\
\text { tersangka } \\
\text { terdakwa pada setiap } \\
\text { tingkat pemeriksaan } \\
\text { meliputi } \\
\text { penyidikan, } \\
\text { penuntutan, } \\
\text { pemeriksaan } \\
\text { pengadilan }\end{array}$ & \\
\hline $\begin{array}{l}\text { Pelaksanaan } \\
\text { pengaturan } \\
\text { pemberian } \\
\text { perlindungan } \\
\text { saksi }\end{array}$ & 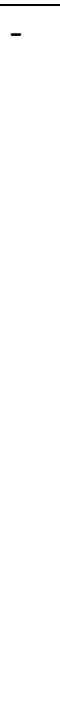 & 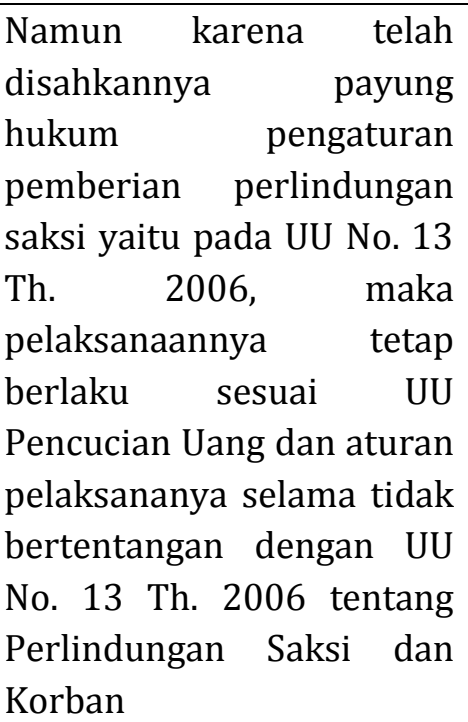 & 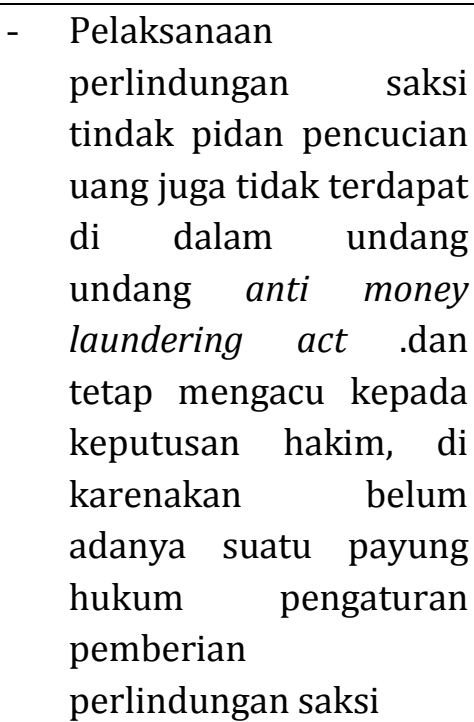 \\
\hline $\begin{array}{l}\text { Pelaksana } \\
\text { perlindungan } \\
\text { saksi }\end{array}$ & & $\begin{array}{l}\text { Mengacupengaturan } \\
\text { undang-undang payung } \\
\text { Undang-Undang No } 13 \text { Th. } \\
\text { 2006, seharusnya yang } \\
\text { menjadi pelaksana adalah } \\
\text { LPSK, yang sampai saat ini } \\
\text { pembentukannya } \\
\text { terhambat. } \\
\text { Jadi pelaksananya selama } \\
\text { ini (perlindungan khusus) } \\
\text { dilakukan olehKepolisian. }\end{array}$ & 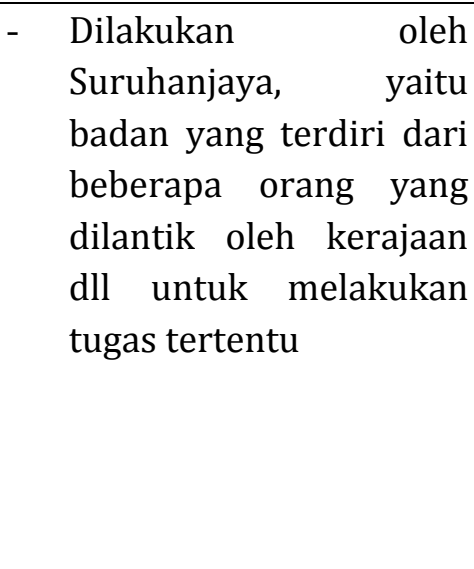 \\
\hline
\end{tabular}

Dari tabel diatas penulis menarik kesimpulan bahwa terdapat persamaan dan perbedaan serta kelebihan dan kekurangan masing-masing negara dalam memberikan perlindungan terhadap saksi tindak pidana pencucian uang yaitu :

a. Persamaan dan perbedaan

1) Persamaan

Persamaan dari perlindungan saksi tindak pidana pencucian uang di negara Indonesia adalah sama sama memberikan perlindungan terhadap saksi dan pelapor tindak pidana pencucian uang saja, sedangkan 
2) Perbedaan

Baik dari bentuk perlindungannya maupun subyek yang dilindungi. Akta Pencegahan Pengubahan Wang Haram, Pencegahan Pembiayaan Keganasan dan Hasil daripada Aktiviti Haram 2001 (AKTA 613) negara Malaysia hanya memberikan suatu bentuk perlindungan bagi saksi pelapor (pemberi maklumat) yaitu bagi mereka yang mengungkapkan atau menyediakan informasi dalam suatu laporan tentang adanya tindak pidana pencucian uang (Pasal 24). Sedangkan Undang-Undang No. 8 Tahun 2010 tentang Pencegahan dan Pemberantasan Tindak Pidana Pencucian Uang (UU TPPU) memberikan perlindungan yang ditujukan kepada saksi, pelapor, dan keluarga saksi/pelapor (Pasal 8387).

Berkaitan dengan bentuk perlindungan yang diberikan, pada Akta Pencegahan Pengubahan Wang Haram, Pencegahan Pembiayaan Keganasan dan Hasil daripada Aktiviti Haram 2001 (AKTA 613), hanya memberikan pengaturan mengenai perlindungan hukum saja, yaitu adanya ketentuan bagi saksi pelapor tidak dapat dikenakan upaya hukum baik secara pidana, perdata maupun upaya ketertiban lainnya atas informasi yang ia berikan. Pada UU TPPU diberikan perlindungan khusus dan perlindungan hukum kepada saksi, pelapor, dan keluarga saksi/pelapor. Perlindungan hukum seperti apa yang diatur dalam Akta Pencegahan Pengubahan Wang Haram, Pencegahan Pembiayaan Keganasan dan Hasil daripada Aktiviti Haram 2001 (AKTA 613), yaitu tidak adapat dilakukan tindakan hukum secara perdata dan pidana terhadap saksi, pelapor, dan keluarga saksi/pelapor. Sedangkan pengaturan megenai perlindungan khusus di Indonesia dibedakan menjadi empat macam, yaitu : perlindungan atas keamanan pribadi dari ancaman fisik atau mental, perlindungan terhadap harta yang harta bergerak dan tidak bergerak, terutama yang paling memungkinkan menjadi sasaran gangguan pihak pelaku, perahasiaan identitas atau penyamaran dan yang terakhir perlindungan untuk memberikan keterangan tanpa bertatap muka secara langsung dengan terdakwa. Pada perlindungan untuk memberikan keterangan tanpa bertatap muka secara langsung dengan terdakwa dapat memungkinkan pengggunaan vidio link untk pemeriksaannya.

Pada pelaksanaan Perlindungan saksi pada Akta Pencegahan Pengubahan Wang Haram, Pencegahan Pembiayaan Keganasan dan Hasil daripada Aktiviti Haram 2001 (AKTA 613)hanya mengacu pada Akta Pencegahan Pengubahan Wang Haram, Pencegahan Pembiayaan Keganasan dan Hasil daripada Aktiviti Haram 2001 (AKTA 613) tersebut saja, karena pengaturan payung hukum undang-undang perlindungan saksi belum ada dan sedang dalam tahap akhir di parlimen.

Di UU TPPU sendiri pelaksanaannya mengacu pada undang-undang payung perlindungan saksi sehingga tidak boleh bertentang dengan undang-undang payung perlindungan saksi (UU No. 13 tahun 2006) tersebut. Pelaksana perlindungan saksi pencucian uang di Malaysia dilaksanakan olehSuruhanjaya, yaitu badan yang terdiri dari beberapa 
orang yang dilantik oleh kerajaan dll untuk melakukan tugas tertentu. Sedangkan di Indoneisa diatur mengenai pelaksana perlindungan khusus kepada saksi dilakukan oleh Negara melalui Kepolisian Negara Republik Indonesia, sesuai dalam PP No. 57 Th. 2003. Mengacu pengaturan undang-undang payung Undang-Undang No 13 Th. 2006, seharusnya yang menjadi pelaksana adalah LPSK, yang sampai saat ini pembentukannya terhambat. Jadi pelaksananya selama ini (perlindungan khusus) dilakukan oleh Kepolisian.

b. Keunggulan dan kelemahan

Dari tabel di atas terlihat jelas keunggulan dari negara Indonesia dalam melakukan perlindungan terhadap saksi tindak pidana pencucian uang, mulai dari Baik dari bentuk perlindungannya maupun subyek yang dilindungi. Akta Pencegahan Pengubahan Wang Haram, Pencegahan Pembiayaan Keganasan dan Hasil daripada Aktiviti Haram 2001 (AKTA 613).Negara Malaysia hanya memberikan suatu bentuk perlindungan bagi saksi pelapor (pemberi maklumat) yaitu bagi mereka yang mengungkapkan atau menyediakan informasi dalam suatu laporan tentang adanya tindak pidana pencucian uang (Pasal 24). Sedangkan Undang-Undang No. 8 Tahun 2010 tentang Pencegahan dan Pemberantasan Tindak Pidana Pencucian Uang (UU TPPU) memberikan perlindungan yang ditujukan kepada saksi, pelapor, dan keluarga saksi/pelapor (Pasal 83-87).

Berkaitan dengan bentuk perlindungan yang diberikan, pada AMLA, hanya memberikan pengaturan mengenai perlindungan hukum saja, yaitu adanya ketentuan bagi saksi pelapor tidak dapat dikenakan upaya hukum baik secara pidana, perdata maupun upaya ketertiban lainnya atas informasi yang ia berikan. Pada UU TPPU diberikan perlindungan khusus dan perlindungan hukum kepada saksi, pelapor, dan keluarga saksi/pelapor. Perlindungan hukum seperti apa yang diatur dalam Akta Pencegahan Pengubahan Wang Haram, Pencegahan Pembiayaan Keganasan dan Hasil daripada Aktiviti Haram 2001 (AKTA 613), yaitu tidak adapat dilakukan tindakan hukum secara perdata dan pidana terhadap saksi, pelapor, dan keluarga saksi/pelapor. Sedangkan pengaturan megenai perlindungan khusus di Indonesia dibedakan menjadi empat macam, yaitu : perlindungan atas keamanan pribadi dari ancaman fisik atau mental, perlindungan terhadap harta yang harta bergerak dan tidak bergerak, terutama yang paling memungkinkan menjadi sasaran gangguan pihak pelaku, perahasiaan identitas atau penyamaran dan yang terakhir perlindungan untuk memberikan keterangan tanpa bertatap muka secara langsung dengan terdakwa. Pada perlindungan untuk memberikan keterangan tanpa bertatap muka secara langsung dengan terdakwa dapat memungkinkan pengggunaan vidio link untk pemeriksaannya.

Dari uraian di atas, penulis dapat menyimpulkan bahwa baik negara Indonesia maupun negara Malaysia memiliki peraturan masing-masing untuk mewujudkan perlindungan saksi tindak pidanan pencucian bagi warganya demi mencapai kepentingan terbaik bagi warganya.Perlindungan saksi tindak pidana pencucian uang di negara Indonesia dianggap mampu memberikan perlindungan terbaik bagi 
warganya demi kepentingan pemberantasan tindak pidana pencucian uang. Hal demikian dapat menjadi contoh negara lain dalam memberantas tindak pidana pencucian uang.

\section{SIMPULAN}

Perbedaan perlindungan saksi tindak pidana pencucian uang pada masingmasing negara terlihat sangat jelas, Pemberantasan Tindak Pidana Pencucian Uang di Indonesia diatur mengenai ketentuan perlindungan saksi. Perlindungan saksi yang dianut merupakan perlindungan hukum dan perlindungan khusus terhadap ancaman yang ditujukan terhadap saksi, pelapor, keluarga saksi/pelapor. Sedangkan di Malaysia Perlindungan ditujukan hanya kepada saksi pelapor dengan jenis perlindungan hukum. Selama proses persidangan, otomatis seorang saksi tidak akan mendapat perlindungan. Sedangkan persamaannya adalah kedua negara sama sama memberikan perlindungan kepada saksi tindak pidana pencucian uang walaupun pemberian perlindungan di Indonesia diatur lebih terperinci. Kelebihan di Indonesia adalah memberikan perlindungan lebih terperinci mulai dari penyidikan hingga persidangan. Kelemahan dari undang-undang ini adalah Aturan perjanjian yang dilakukan apabila seorang saksi berasal dari luar wilayah Indonesia belum jelas.

\section{DAFTAR PUSTAKA}

\section{Dokumen Hukum}

Akta Pencegahan Pengubahan Wang Haram, Pencegahan Pembiayaan Keganasan dan Hasil daripada Aktiviti Haram 2001 (AKTA 613).

Republik Indonesia, Peraturan Kepala Kepolisian Negara Tentang Tata Cara Pemberian Perlindungan Khusus terhadap Pelapor dan Saksi dalam Tindak Pidana Pencucian Uang. Peraturan Kepala Kepolisian Nomor Pol. 17 Tahun 2005.

Peraturan Pemerintah Tentang Tata Cara Perlindungan Khusus bagi Pelapor dan Saksi Tindak Pidana Pencucian Uang. Peraturan Pemerintah Nomor 57 Tahun 2003. LNRI Tahun 2003 Nomor 126. TLNRI Nomor 4335.

Undang-Undang Tentang Pencegahan dan Pemberantasan Tindak Pidana Pencucian Uang. Undang-Undang Nomor 8 Tahun 2010. LNRI Tahun 2010 Nomor 122, TLNRI Nomor 5164.

\section{Buku}

Ali, Zainuddin. Metode Penelitian Hukum, Jakarta: Sinar Grafika, 2009.

Arief, Barda Nawawi. Perbandingan Hukum Pidana Edisi Revisi, Jakarta: Rajawali Pers, 2014.

Attasasmita, Romli. Perbandingan Hukum Pidana, Bandung: Mandar Maju, 1996.

Garnasih, Yenti. Penegakan Hukum Anti Pencucian Uang dan Permasalahannya di Indonesia, Depok: Rajawali Pers, 2017. 
Hadjon, Philipus M. Perbandingan Hukum Bagi Rakyat Indonesia, Surabaya: Bina Ilmu, 1987.

Hamzah, Andi. Hukum Pidana Indonesia, Jakarta: Sinar Grafika, 2007.

Marbun, Rocky. Cerdik \& Taktis Mengenai Kasus Hukum, Jakarta: Visimedia, 2009.

Marzuki, Peter Mahmud. Penelitian Hukum Pidana, Jakarta: Kencana, 2006.

Mertokusumo, Soedikno. Mengenal Hukum Suatu Pengantar, Jogjakarta: Liberty, 1991.

Mulyadi, Lilik. Tindak Pidana Korupsi di Indonesia: Normatif, Teoritis, Praktik dan Masalahnya, Bandung: PT Alumni, 2011.

Nasution, Bismar. Resim Anti Money Laundering, Bandung: Books Terrace, 2008.

Poerwadarminta, Wjs. Kamus Umum Bahasa Indonesia, Jakarta: Balai Pustaka, 1961.

Samosir, C. Djisman. Segenggam Tentang Hukum Acara Pidana, Bandung: Nuansa Indah, 2013.

Sembiring, K. Kueteh. Sumber-Sumber Hukum, Medan: Fakultas Hukum Universitas Sumatera Utara, 1978.

Sjahdeini, Sutan Remy. Seluk Beluk Tindak Pidana Pencucian Uang Dan Pembiayaan Terorisme, Jakarta: Pusat Utama Grafiti, 2004.

Wati, Ai dan Beni Ahmad Saebani. Perbandingan Sistem Hukum Pidana, Bandung: Pustaka Setia, 2016.

\section{Jurnal}

Arsyad, Apriliani dan Kabib Nawawi, "Meningkatkan Pemahaman Masyarakat terhadap Undang-Undang No. 31 Tahun 2014 Tentang Perlindungan Saksi dan Korban di Desa Kau Aro Kecamatan Muara Bulian Kabupaten Batanghari", Jurnal Pengabdian Pada Masyarakat, Vol. 31, No. 2, (2016). https://scholar.google.co.id/citations?user=8InHKN8AAAAJ\&hl=id.

Hafrida, "Perekaman Proses Persidangan Pada Pengadilan Negeri Ditinjau Dari Aspek Hukum Acara Pidana", Jurnal Ilmu Hukum, Vol. 5, No. 1, (2014). https://scholar.google.com/citations?user=xT8MpbIAAAAJ\&hl=en.

Najemi, Andi, dkk, "Perlindungan Hukum Terhadap Anak Korban Perkosaan di Wilayah Hukum Pengadilan Negeri Jambi”, Jurnal Ilmu Hukum, Vol. 7, No. 1, (2016). https://repository.unja.ac.id/610/1/5.\%20Nys.\%20ARfa.pdf

Rinaldi, Yanis, dkk, “Gratifikasi Sebagai Tindak Pidana Korupsi Terkait Adanya Laporan Penerimaan Gratifikasi”, Kanun Jurnal Ilmu Hukum, Vol. 19, No. 2, (2017). https://scholar.google.com/citations?user=xT8MpbIAAAAJ\&hl=en 